\title{
PHYTOPLANKTON AND MACROFAUNA IN THE LOW SALINITY PONDS OF A PRODUCTIVE SOLAR SALTWORKS: SPATIAL VARIABILITY OF COMMUNITY STRUCTURE AND ITS MAJOR ABIOTIC DETERMINANTS
}

\author{
A. EVAGELOPOULOS* \\ E. SPYRAKOS \\ D. KOUTSOUBAS
}

Received: $23 / 11 / 08$

Accepted: 10/12/08

\author{
Department of Marine Sciences, Faculty of the Environment \\ University of the Aegean \\ University Hill, 81100 Mytilene, Greece
}

*to whom all correspondence should be addressed: e-mail: tevagelo@marine.aegean.gr

\begin{abstract}
This paper focuses on the structure of the phytoplankton and macrobenthic invertebrates communities in a productive solar saltworks, as well as the major abiotic determinants of the observed biotic patterns. The observed patterns in the structure of the biotic communities attest that the ecosystem of the low salinity ponds of Kalloni Saltworks is similar to a productive coastal lagoon. Major abiotic determinants include the salinity and confinement gradients, as well as inorganic nutrients loads. The episodic enrichment of the water column in the ponds with either new nutrients from the incoming seawater, or regenerated nutrients released from the sediment, was shown to stimulate the growth to bloom levels of phytoplankton species indicative of organic enrichment and coastal eutrophication. Algal biomass and the accumulated detritus and organic matter on and within the sediment are exploited by opportunistic herbivores and deposit feeders tolerant to organic enrichment. Management measures are needed for the mitigation of the productiveness of the low salinity ponds, e.g. lower water residence times, a shallower water column, facilitation of the oxygenation of the sediment, sediment removal in winter and culture and harvesting of the naturally occuring, edible Cerastoderma glaucum bivalves.
\end{abstract}

KEYWORDS salinas, salinity, confinement, eutrophication, inorganic nutrients, community structure

\section{INTRODUCTION}

Solar saltworks (salinas, salterns, saltfields) are man-made systems of interconnected ponds for the extraction of salt from seawater, by means of solar and wind evaporation (Korovessis and Lekkas, 2000). At the same time, they are coastal aquatic ecosystems that manifest considerable environmental heterogeneity (Davis, 2000), as they consist of a range of habitat types that develop along a steep salinity gradient (seawater salinity - $300 \mathrm{psu}$ ). Solar saltworks are usually regarded as coastal wetlands (Costa et al., 1996), or closely related to salt marshes, as the latter often incorporate natural "salt pans" and "salt ponds" (Pennings and Bertness, 2001).

The variability of the physical and chemical regimes in the abiotic environment of a solar saltworks is reflected on the variability of the biota that are adapted to and colonize each habitat type in the solar saltworks system (Davis, 2000). Where salinity is not very high (i.e. in the initial ponds), biodiversity is significant (Evagelopoulos and Koutsoubas, 2008), but in the extreme, hyperhaline conditions of the high salinity ponds and the crystallizers, the environment is too harsh and biodiversity is consequently limited, many taxonomic groups are absent and halophilic and halotolerant taxa persist and thrive (Rodriguez-Valera, 1988).

The biota of solar saltworks ecosystems have attracted the attention of both the scientific community and the general public, particularly the avifauna (e.g. Britton and Johnson, 1987; Sadoul et al., 1998; Walmsley, 2000). Furthermore, the red halophilic bacteria (e.g. 
Halobacterium, Halococcus) and halotolerant microalgae (e.g. Dunaliella), as well as the "brine shrimp" Artemia, all typically inhabiting the high salinity ponds or the crystallizers, have been the subjects of considerable scientific research and applications in such fields as aquaculture and biotechnology (e.g. Persoone et al., 1980; Avron and Ben Amotz, 1992; Borowitzka and Borowitzka, 1998; Oren, 2002; Dolapsakis et al., 2005).

There are a number of studies that have dealt with the phytoplankton communities of solar saltworks, usually examining a limited number of ponds along the complete salinity range (e.g. Pedròs-Alió et al., 2000; Ayadi et al., 2004; Segal et al., 2006). However, the structural changes that occur in the phytoplankton community across the ecotone that exists between the initial pond of a saltworks and the adjacent nearshore marine environment are largely unexplored. The phytoplankton flora of greek solar saltworks in particular is poorly known, as few published studies exist (e.g. Dolapsakis et al., 2005; Evagelopoulos et al., 2007; Evagelopoulos, 2008).

Although the macrofauna community is among the less explored biotic components of solar saltworks, it is actually very important as macrobenthic invertebrates (1) constitute a fundamental food resource for the waterfowl (Britton and Johnson, 1987), (2) interact with other organisms through trophic relationships (Dauer, 1993) and (3) have a considerable impact on ecosystem functioning by mediating in processes like sediment bioturbation (Jumars and Nowell, 1984) and removal of particles from the water by suspension feeding (Dame, 1993). Studies that consider the macrofauna communities of solar saltworks are very few (e.g. Vieira and Galhano, 1985; Britton and Johnson, 1987; Vieira and Amat, 1997; Pavlova et al., 1998). Studies examining the macrobenthic invertebrates of greek solar saltworks in particular have only recently been published (Evagelopoulos and Koutsoubas, 2008; Evagelopoulos et al., 2008; Evagelopoulos, 2008).

This paper aims to provide new information, as well as to review existing information, on the variability of the composition and structure of phytoplankton and macrobenthic invertebrates communities, as well as the major abiotic determinants of the observed biotic patterns, in a productive solar saltworks. Variability is examined (a) along the salinity/confinement gradient at successive low salinity ponds and (b) across the ecotone that takes place between the initial pond of a saltworks and the adjacent nearshore marine environment.

\section{MATERIALS AND METHODS}

The study area (Figure 1) is the low salinity ponds of Kalloni Saltworks (Lesvos Island, N.E. Aegean Sea, Greece). Kalloni Saltworks is located at the northeastern coast of Kalloni Gulf, which is a productive, semi-enclosed gulf (Panayotidis and Klaudatos, 1997). The application of fertilizers in its catchment area takes place mainly in winter, thus coinciding with the period of high precipitation. The catchment area is drained through a number of intermittent rivers, located mainly at the northern part of the gulf, hence in the proximity of Kalloni Saltworks.
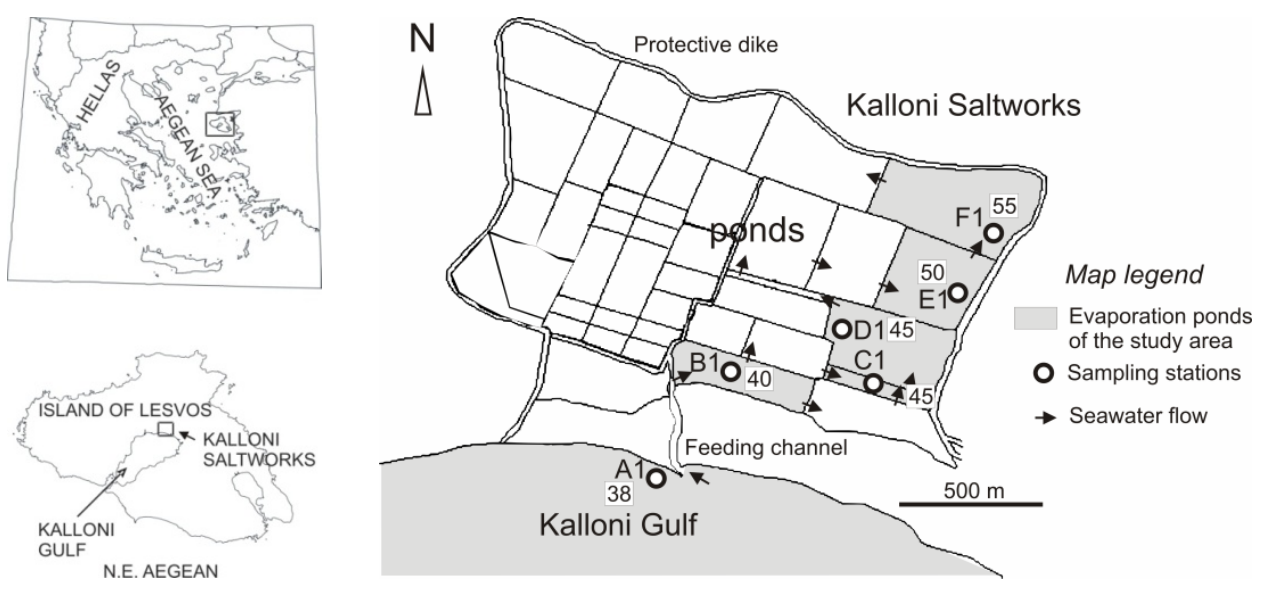

Figure 1. Map of the study area, indicating the sampling stations and the salinity gradient (psu) 
Marine macrobenthic invertebrates are expected to disappear in salinities higher than 70 psu (Britton and Johnson, 1987), and therefore, this paper focuses on the low salinity part of Kalloni Saltworks. Sampling was carried out at five stations at five low salinity ponds, as well as one additional station at the adjacent nearshore marine environment of Kalloni Gulf, in November 2004 (Figure 1). The salinity gradient in the study area ranged from seawater salinity to $55 \mathrm{psu}$ at the last pond. Water column samples (four replicates) for the phytoplankton analyses as well as sediment samples (five replicates) for the analyses of the macrobenthic invertebrates were collected. The sediment samples $\left(0.03 \mathrm{~m}^{2}\right)$ were collected by means of a box-corer type sampler and were subsequently sieved through a $0.5 \mathrm{~mm}$ mesh size net (Dybern et al., 1976). The samples were fixed with $4 \%$ formaldehyde and stained with Rose Bengal (Eleutheriou and Moore, 2005). The invertebrates were sorted out in the laboratory, identified and counted. Phytoplankton species were identified and counted in samples fixed with Lugol solution (Edler, 1979), according to the Utermöhl method (Utermöhl, 1958). In this paper, the taxa defined as abundant at a sampling station were the taxa that constituted collectively at least $75 \%$ of the total numerical abundance at the station.

\section{RESULTS}

The structure of both phytoplankton and macrofauna communities was differentiated across the nearshore marine environment - pond environment ecotone and was also variable along the salinity gradient in the ponds.

Phytoplankton in the study area were identified into a total of 48 taxa, belonging to 7 classes, i.e. Bacillariophyceae, Dinophyceae, Euglenophyceae, Cryptophyceae, Cyanophyceae, Haptophyceae, Dictyochophyceae and a group of unidentified nanophytoplaktonic species. Most of the taxa belonged to Bacillariophyceae and Dinophyceae. The photoautotrophic ciliate Mesodinium rubrum was also recorded in the study area.

Table 1. List of the abundant phytoplanktonic taxa (also including the photoautotrophic ciliate Mesodinium rubrum) in the study area, indicating the taxonomic group they belong to, their numerical abundance (cells $\mathrm{ml}^{-1}$ ) and the corresponding percentage of the total numerical abundance at each station

\begin{tabular}{|c|c|c|c|c|}
\hline STATION & ABUNDANT TAXA & GROUP & N. ABUND. & N. ABUND. \% \\
\hline \multirow[t]{5}{*}{ A1 } & $\begin{array}{l}\text { Thalassionema spp. } \\
\text { nanophytoplankton }\end{array}$ & Bacillariophyceae & 12.33 & 45.43 \\
\hline & $\begin{array}{l}\text { spp. } \\
\text { Cylindrotheca }\end{array}$ & Bacillariophyceae & 5.86 & 21.58 \\
\hline & closterium & & 1.43 & 5.27 \\
\hline & Prorocentrum & Dinophyceae & & \\
\hline & sigmoides & & 1.28 & 4.71 \\
\hline B1 & Euglena acusformis & Euglenophyceae & 1968.18 & 94.33 \\
\hline \multirow[t]{4}{*}{ C1 } & Euglena acusformis & Euglenophyceae & 439.60 & 58.19 \\
\hline & Oxyrrhis marina & Dinophyceae & 105.03 & 13.90 \\
\hline & Gymnodinium & Dinophyceae & & \\
\hline & sanguineum & & 80.47 & 10.65 \\
\hline D1 & Mesodinium rubrum & Ciliophora & 405.88 & 76.34 \\
\hline \multirow[t]{3}{*}{ E1 } & $\begin{array}{l}\text { Cylindrotheca } \\
\text { closterium }\end{array}$ & Bacillariophyceae & 407.27 & 65.20 \\
\hline & thecate dinophyceae & Dinophyceae & & \\
\hline & spp. & & 146.05 & 23.38 \\
\hline \multirow[t]{4}{*}{ F1 } & $\begin{array}{l}\text { Cryptophyceae sp. } 1 \\
\text { nanophytoplankton }\end{array}$ & Cryptophyceae & 52.07 & 24.96 \\
\hline & $\begin{array}{l}\text { spp. } \\
\text { Cvlindrotheca }\end{array}$ & Bacillariophvceae & 42.21 & 20.23 \\
\hline & closterium & & 36.35 & 17.43 \\
\hline & Cryptophyceae sp. 2 & Cryptophyceae & 28.38 & 13.61 \\
\hline
\end{tabular}


The distribution of the phytoplankton classes in the study area and the abundant taxa recorded at each station are presented in Figure $2 a$ and Table 1 respectively. Haptophyceae and Dictyochophyceae were recorded only at the A1 station. On the other hand, Euglenophyceae (Euglena acusformis), the dinophyceans Oxyrrhis marina and Gymnodinium sanguineum, as well as Mesodinium rubrum, were all recorded at the ponds stations only. More phytoplankton taxa were recorded at the A1 station (33) than at any station in the saltworks ponds (7 - 14) (Figure 2b).

Autoecological traits of common phytoplankton taxa in the study area are presented in Table 2. Species typical of both coastal waters and brackish waters were recorded at the A1 station, whereas the abundant species in the ponds are species that commonly occur in brackish waters or organically enriched lagoons. Benthic pennate diatoms were not abundant at any station.

The variation of phytoplankton total numerical abundance in the study area is presented in Figure 2a. Maximum total numerical abundance was recorded at the B1 station, due to a Euglena acusformis bloom (2087 cells $\mathrm{ml}^{-1}$ ), whereas minimum total numerical abundance (26 cells $\mathrm{ml}^{-1}$ ) was recorded at the $\mathrm{A} 1$ station. Mesodinium rubrum was dominant at the D1 station, where its numerical abundance reached bloom levels (406 cells $\mathrm{ml}^{-1}$ ).

Macrobenthic invertebrates in the study area were identified into a total of 54 taxa. Most of the taxa identified belonged to Mollusca, followed by Polychaeta and Crustacea. Insecta and Nemertea were represented by a single species each.

The distribution of macrofauna classes in the study area and the abundant taxa recorded at each station are presented in Figure $2 \mathrm{c}$ and Table 3 respectively. Mollusca, Polychaeta and Crustacea were found at all stations. Insecta were represented by the larvae of a single Chironomidae species at the C1, D1 and E1 stations, whereas the nemertean species was found at the A1 station only. Species richness of macrobenthic invertebrates gradually declined along the salinity gradient, from a maximum of 38 species at the A1 station to a minimum of 4 species at the F1 station (Figure $2 \mathrm{~d}$ ).

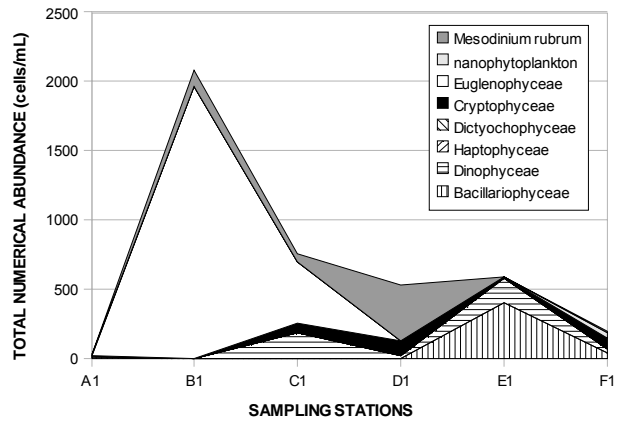

(a)

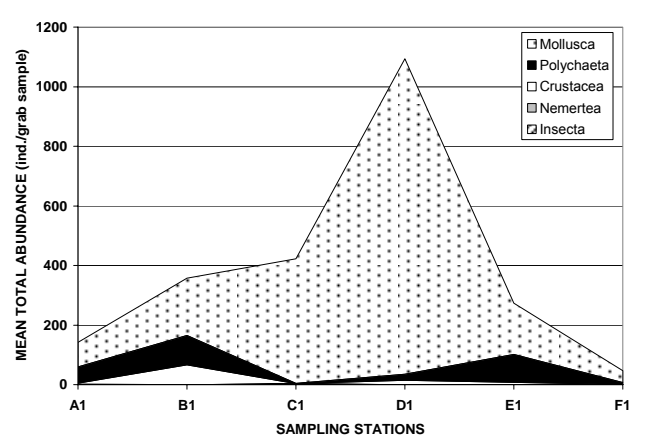

(c)

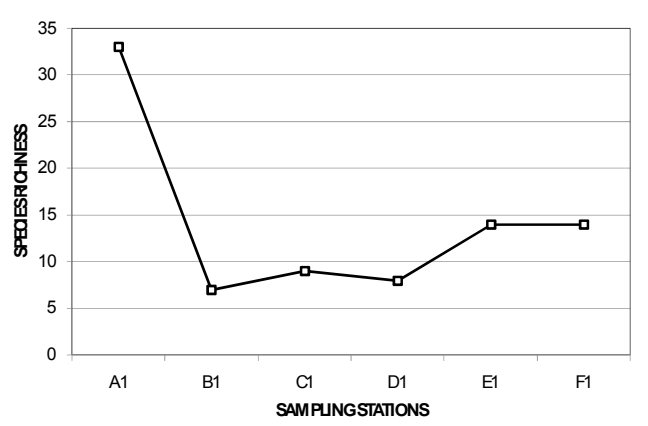

(b)

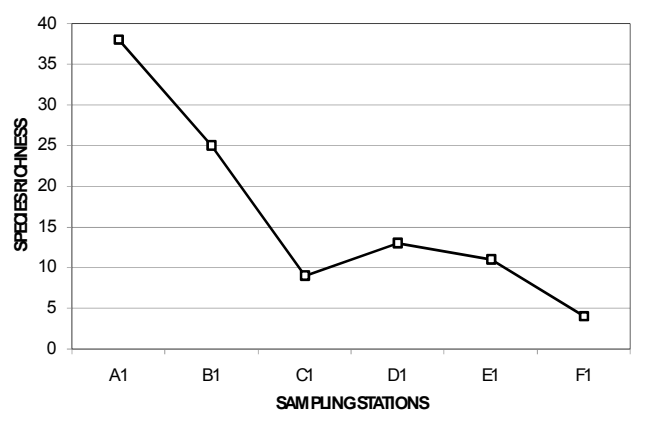

(d)

Figure 2. Spatial variations in the study area of (a) phytoplankton mean total numerical abundance (indicating the contribution of each taxonomic group), (b) phytoplankton species richness, (c) macrobenthic invertebrates mean total numerical abundance (indicating the contribution of each taxonomic group), (d) macrobenthic invertebrates species richness 
Table 2. Autoecological traits of common phytoplanktonic taxa (also including the photoautotrophic ciliate Mesodinium rubrum) in the study area

\begin{tabular}{lccc}
\hline TAXA & $\begin{array}{c}\text { ABUNDANT AT } \\
\text { STATIONS }\end{array}$ & DOMAIN & HABITAT \\
\hline $\begin{array}{l}\text { Bacillariophyceae } \\
\text { Thalassionema spp. }\end{array}$ & $\mathrm{A} 1$ & $\mathrm{PL}$ & - \\
$\begin{array}{l}\text { Cylindrotheca closterium } \\
\text { Euglenophyceae }\end{array}$ & $\mathrm{A} 1, \mathrm{E} 1, \mathrm{~F} 1$ & $\mathrm{PL} / \mathrm{BE}$ & $\mathrm{CW} / \mathrm{BW}$ \\
$\begin{array}{l}\text { Euglena acusformis } \\
\text { Dinophyceae }\end{array}$ & $\mathrm{B} 1, \mathrm{C} 1$ & $\mathrm{PL}$ & $\mathrm{CW} / \mathrm{OM}$ \\
$\begin{array}{l}\text { Gymnodinium sanguineum } \\
\text { Oxyrrhis marina }\end{array}$ & $\mathrm{C} 1$ & & \\
$\begin{array}{l}\text { Prorocentrum sigmoides } \\
\text { Cryptophyceae }\end{array}$ & $\mathrm{C} 1$ & $\mathrm{PL}$ & $\mathrm{CW} / \mathrm{BW}$ \\
$\begin{array}{l}\text { Cryptophyceae sp. 1 } \\
\text { Cryptophyceae sp. 2 }\end{array}$ & $\mathrm{A} 1$ & $\mathrm{PL}$ & $\mathrm{CW} / \mathrm{BW}$ \\
Spirulina sp. & $\mathrm{F} 1$ & $\mathrm{PL}$ & $\mathrm{CW} / \mathrm{BW}$ \\
\hline $\begin{array}{l}\text { Ciliophora } \\
\text { Mesodinium rubrum }\end{array}$ & $\mathrm{F} 1$ & $\mathrm{PL}$ & \\
\hline DOMAN: Planktonic (PL); & & $\mathrm{PL}$ & - \\
\hline
\end{tabular}

DOMAIN: planktonic (PL); benthic (BE)

HABITAT: coastal waters (CW); brackish waters (BW); enriched in organic mater (OM)

Table 3. List of the abundant macrobenthic invertebrate taxa in the study area, indicating the taxonomic group they belong to, their numerical abundance (ind. grab sample ${ }^{-1}$ ) and the corresponding percentage of the total numerical abundance at each station

\begin{tabular}{|c|c|c|c|c|}
\hline STATION & ABUNDANT TAXA & GROUP & N. ABUND. & N. ABUND. \% \\
\hline \multirow[t]{7}{*}{ A1 } & Bittium reticulatum & Gastropoda & 46.8 & 32.91 \\
\hline & Malacoceros & & & \\
\hline & fuliginosus & Polychaeta & 36.8 & 25.88 \\
\hline & Rissoa ventricosa & Gastropoda & 8.6 & 6.05 \\
\hline & Tellina donacina & Bivalvia & 8.6 & 6.05 \\
\hline & Capitella capitata & Polychaeta & 4.6 & 3.23 \\
\hline & Rissoa guerinii & Gastropoda & 4.0 & 2.81 \\
\hline \multirow[t]{4}{*}{ B1 } & Hydrobia acuta & Gastropoda & 156.6 & 40.43 \\
\hline & $\begin{array}{l}\text { Microdeutopus } \\
\text { gryllotalpa }\end{array}$ & Crustacea & 57.8 & 14.92 \\
\hline & Capitella capitata & Polychaeta & 55.6 & 14.36 \\
\hline & $\begin{array}{l}\text { Malacoceros } \\
\text { fuliginosus }\end{array}$ & Polychaeta & 44.8 & 11.55 \\
\hline C1 & Hydrobia acuta & Gastropoda & 367.2 & 86.81 \\
\hline D1 & Hydrobia acuta & Gastropoda & 1047.6 & 95.79 \\
\hline \multirow[t]{2}{*}{ E1 } & Hydrobia acuta & Gastropoda & 150.0 & 54.78 \\
\hline & Capitella capitata & Polychaeta & 89.8 & 32.80 \\
\hline F1 & Hydrobia acuta & Gastropoda & 38.2 & 81.28 \\
\hline
\end{tabular}


Autoecological traits of common macrofauna taxa in the study area are presented in Table 4. Marine species were abundant at the A1 station, whereas the species that were abundant at the ponds stations are typical lagoonal. Species that are usually abundant in organically enriched sediments in marine, estuarine or lagoonal habitats were abundant at the ponds stations B1 and E1, as well as at the A1 station. Moreover, species that are associated to macrophytic vegetation were also abundant in the study area and Pirenella conica, a gastropod that prefers cyanophycean mats as its food source, was common in the last ponds. The abundant macrofauna species in the study area are epifaunal herbivores/detritivores or infaunal deposit or suspension feeders, while many of the abundant species at the ponds stations are regarded as species tolerant to disturbance or opportunistic species.

The variation of macrofauna total numerical abundance in the study area is presented in Figure 2c. Total numerical abundance gradually increased along the salinity gradient, starting from relatively low values at the A1 station (142 ind. sample ${ }^{-1}$ ) and reaching its maximum value (1094 ind. sample ${ }^{-1}$ ) at the D1 station, mainly due to the high abundance of the gastropod Hydrobia acuta. However, after the D1 station, total numerical abundance gradually declined to its minimum at the $\mathrm{F} 1$ station (47 ind. sample ${ }^{-1}$ ). Total numerical abundance was dominated by mollusca at all stations (Figure 2c). The most abundant molluscan taxa were the gastropods Hydrobia acuta at all the ponds stations and Bittium reticulatum at the A1 station. The most abundant species of polychaetes were Malacoceros fuliginosus and Capitella capitata. The amphipod Microdeutopus gryllotalpa was the only abundant crustacean species.

Table 4. Autoecological traits of common macroinvertebrate taxa in the study area

\begin{tabular}{|c|c|c|c|c|c|c|}
\hline TAXA & $\begin{array}{c}\text { ABUNDANT } \\
\text { AT } \\
\text { STATIONS }\end{array}$ & HABITAT & SUBSTRATE & POSITION & $\begin{array}{l}\text { FEEDING } \\
\text { METHOD }\end{array}$ & BENTIX \\
\hline \multicolumn{7}{|c|}{ Mollusca: Gastropoda } \\
\hline Bittium reticulatum & A1 & MAR & SOFT/VEG & EPI & HER & 1 \\
\hline Cyclope neritea & & MAR/LAG & SOFT & EPI & CAR/DF & 1 \\
\hline Hydrobia acuta & $\begin{array}{c}\text { B1, C1, D1, } \\
\text { E1, F1 }\end{array}$ & LAG & SOFT/VEG & EPI & HER/DF & 1 \\
\hline Pirenella conica & & LAG & SOFT/ALGMAT & EPI & HER & - \\
\hline \multicolumn{7}{|l|}{ Mollusca: Bivalvia } \\
\hline Abra segmentum & & LAG & SOFT & INF & DF & 2 \\
\hline $\begin{array}{l}\text { Cerastoderma } \\
\text { glaucum }\end{array}$ & & LAG & SOFT/VEG & EPI/INF & SF & 2 \\
\hline Tellina donacina & $\mathrm{A} 1$ & MAR & SOFT & INF & DF/SF & 1 \\
\hline \multicolumn{7}{|l|}{ Polychaeta } \\
\hline Capitella capitata & A1, B1, E1 & MAR/EST/LAG & SOFT/OM & INF & DF & 2 \\
\hline Hediste diversicolor & & MAR/EST/LAG & SOFT/OM & EPI/INF & CAR/HER/DF/SF & 2 \\
\hline Malacoceros & $\mathrm{A} 1, \mathrm{~B} 1$ & & & & & \\
\hline fuliginosus & & MAR/EST/LAG & SOFT/OM & INF & DF/SF & 2 \\
\hline Perinereis cultrifera & & MAR/EST/LAG & SOFT/VEG & $\mathrm{EPI} / \mathrm{INF}$ & CAR & 1 \\
\hline \multicolumn{7}{|l|}{ Crustacea } \\
\hline $\begin{array}{l}\text { Microdeutopus } \\
\text { gryllotalpa }\end{array}$ & B1 & MAR/LAG & SOFT/NEG & EPI & HER & 2 \\
\hline
\end{tabular}

HABITAT: marine (MAR); estuarine (EST); lagoonal (LAG); SUBSTRATE: soft substrate (SOFT); sediment enriched in organic matter (OM); macrophytic vegetation (VEG); microalgal mats (ALGMAT); POSITION: epifaunal (EPI); infaunal (INF); FEEDING METHOD: herbivore/detritivore (HER); suspension feeding (SF); subsurface deposit feeder (SSDF); surface deposit feeder (SDF); carnivore/scavenger (CAR)

BENTIX: species sensitive or indifferent to disturbance (1); species tolerant to disturbance or first-order or secondorder opportunistic species (2) 


\section{DISCUSSION}

In situ observations attest that the abiotic environment of the low salinity ponds of Kalloni Saltworks is similar to that of productive coastal lagoons, although there are important differences in hydrology: Seawater, which in winter may be rich in inorganic nutrients, enters the ponds, but its input is not tidal but controlled by pumping. Unlike coastal lagoons, it is insulated from direct inputs of terrestrial runoff by a dike and winter precipitation is the only freshwater input. Water in the ponds is hyperhaline and a steep salinity gradient is maintained for the production of salt. The water column is shallow, even shallower than in most coastal lagoons and salinity is temporarily variable due to the effect of winter precipitation, while temperature is also temporally very variable. Bottom sediment is muddy and rich in organic matter, like in many productive coastal lagoons (Little, 2000). Finally, blooms of opportunistic, drifting algae (e.g. Enteromorpha), which are indicators of high inorganic nutrient loads (McLusky and Elliott, 2004; Davis, 2006), repeatedly occur in early summer (pers. observ.).

The results of this study, as well as existing information considering the phytoplankton and macrofauna communities of Kalloni Saltworks (Evagelopoulos et al., 2007; Evagelopoulos and Koutsoubas, 2008; Evagelopoulos et al., 2008), further confirm the lagoonal nature of the pond environment in the study area: To begin with, the variability patterns of taxonomic composition and numerical abundance in both phytoplankton and macrofauna, were typical of coastal lagoons. Brackish waters species, including typical lagoonal, were abundant in the ponds, whereas typical marine species either did not occur in the ponds, or their distribution extended no further than the initial ponds. The major abiotic determinants of the observed distribution patterns include the salinity and confinement gradients (Evagelopoulos and Koutsoubas, 2008; Evagelopoulos et al., 2008), as well as the changes in water ionic composition and temperature extreme temporal variations (Britton and Johnson, 1987).

Species richness of both phytoplankton and macrofauna was much lower in the ponds than in the adjacent nearshore marine environment. This is most probably due to the stress that the spatial and temporal variability of the lagoonal environment of the ponds poses for the biota, allowing only the adapted brackish waters and lagoonal species to dominate (Barnes, 1994).

On the other hand, numerical abundance of both phytoplankton and macrofauna was much higher in the ponds than in the adjacent nearshore marine environment. This reflects a high productivity of the ponds ecosystem, which should be attributed mainly to the inorganic nutrients loads of the intake weawater. The birds of the saltworks may be another source of still undetermined importance of inorganic nutrients to the ponds where they feed. It is well known that the lagoonal environment is typically characterised by high primary productivity and a profusion of plant and detrital material, which is not always effectively decomposed and accumulates in the sediment (Little, 2000). The episodic enrichment of the water column in the ponds with inorganic nutrients, which are either new nutrients from the incoming seawater or regenerated nutrients released from the sediment, stimulate the growth to bloom levels of r-selected species indicative of organic enrichment (e.g. Euglena acusformis; Reynolds, 2006) and coastal eutrophication (e.g. Mesodinium rubrum; Williams, 1996). Likewise, the accumulated detritus and organic matter on and within the sediment is exploited by opportunistic deposit feeders (e.g. Capitella capitata, Malacoceros fuliginosus, Microdeutopus gryllotalpa, Chironomidae) tolerant to organic enrichment (Barnes, 1994).

Nevertheless, productive low salinity ponds are not favorable for a solar saltworks (Davis, $1978 ; 1990 ; 2000 ; 2006)$ : The trophic status and ecosystem function of the low salinity ponds affect the abiotic environment and the biota of the higher salinity ponds, as well as the production of salt. Therefore, management measures are needed for the mitigation of the productiveness of the low salinity ponds (Davis, 1978; 1990; 2000; 2006), e.g. lower water residence times, shallower water column, facilitation of the oxygenation of the sediment or sediment removal in winter. Culture and harvesting of the naturally occuring, edible Cerastoderma glaucum bivalves may also help to remove organic matter from the low salinity ponds. 


\section{CONCLUSIONS}

The confirmed lagoonal characteristics of the low salinity ponds of a solar saltworks are of interest to both ecological research of brackish waters ecosystems (Evagelopoulos et al., 2008) and solar saltworks management: The salt pans of solar saltworks can be considered as microcosms that, by allowing direct observations of the activities of their inhabitants, may help in understanding many aspects of brackish waters ecology. The constant maintainenance of the distinctive salinity and confinement gradients in a solar saltworks facilitates the study of their roles as abiotic stressors and determinants of community structure. Besides, the application in productive solar saltworks of management practices based on the ecological knowledge of coastal lagoons seems reasonable and may proove beneficial to the production of salt and the sustainability of the solar saltworks ecosystem.

\section{ACKNOWLEDGEMENTS}

The authors would like to thank the "Hellenic Saltworks S.A." company for their kind allowance of access to company facilities at Kalloni Saltworks for the collection of the samples.

\section{REFERENCES}

Avron M. and Ben-Amotz A., (1992), Dunaliella: Physiology, biochemtistry and biotechnology, CRC, Boca Raton.

Ayadi H., Abib O., Elloumi J., Bouain A. and Sime-Ngando T., (2004), Structure of the phytoplankton communities in two lagoons of different salinity in the Sfax saltern (Tunisia), Journal of Plankton Research, 26(6), 669-679.

Barnes R.S.K., (1994), The brackish-water fauna of Northwestern Europe, Cambridge University Press, Cambridge.

Borowitzka,M.A. and Borowitzka L.J., (1998), Dunaliella, In: Microalgal biotechnology, Borowitzka, M.A. and Borowitzka, L.J. (eds.), Cambridge University Press, Cambridge.

Britton, R. and Johnson A., (1987), An ecological account of a Mediterranean salina: The Salin de Giraurd, Gamargue (S. France), Biological Concervation, 42, 185-230.

Costa L.T., Farinha J.C., Hecker N. and Tomàs Vives P., (1996), Mediterranean Wetland Inventory, A reference manual, Volume I, MedWet/Instituto da Conservação da Natureza/Wetlands International Publication, Lisboa.

Dame R.F., (1993), Bivalve filter feeders in estuarine and coastal ecosystem processes, Springer Verlag, Heidelberg.

Dauer D.M., (1993), Biological criteria, environmental health and estuarine community structure, Marine Pollution Bulletin, 26, 249-257.

Davis J.S., (1978), Biological communities of a nutrient enriched salina, Aquatic Botany, 4, 23-42.

Davis, J.S. (1990), Biological management for the production of salt from seawater, In: Introduction to applied phycology, Akatsuka, I. (ed.)., SPB Academic Publishing, The Hague.

Davis J.S., (2000), Structure, function and management of the biological system for seasonal solar saltworks, GLOBAL NEST: The International Journal, 2(3), 217-226.

Davies J.S., (2006), Biological and physical management information for commercial solar saltworks, In: Ecological importance of solar saltworks, Lekkas T.D. and Korovessis N.A. (eds.), Proceedings of the 1st International Conference on the Ecological Importance of Solar Saltworks (CEISSA 06), Santorini Island, Greece, 20-22 October 2006, GlobalNEST, Athens.

Dolapsakis N., Tafas T., Abatzopoulos T., Ziller S. and Economou-Amilli A., (2005), Abudance and growth response of microalgae at Megalon Embolon solar saltworks in northern Greece: An aquaculture prospect, Journal of Applied Phycology, 17, 39-49.

Dybern B.I., Ackfors H. and Elmgren R., (1976), Recommendations on methods for marine biological studies in the Baltic Sea, The Baltic Marine Biologists 1, Sweden.

Edler L., (1979), Recommendations for marine biological studies in the Baltic Sea. Phytoplankton and chlorophyll, The Baltic Marine Biologists 5, Sweden.

Eleutheriou A. and Moore D.C., (2005), Macrofauna techniques, In: Methods for the study of marine benthos, Eleutheriou, A. and McIntyre, A. (eds.), Blackwell Science, Oxford.

Evagelopoulos A. (2008), Patterns of biodiversity in the coastal wetland ecosystems of Kalloni Saltworks, Lesvos Island, Greece, Doctoral Dissertation, Department of Marine Sciences, University of the Aegean, Mytilene 
Evagelopoulos A., Spyrakos E. and Koutsoubas D., (2007), The biological system of the lower salinity ponds in Kalloni Saltworks (NE. Aegean Sea, Greece): phytoplankton and macrobenthic invertebrates. Transitional Waters Bulletin, 3, 23-25.

Evagelopoulos A. and Koutsoubas D., (2008), Seasonal community structure of the molluscan macrofauna at the marine - lagoonal environmental gradient at Kalloni solar saltworks (Lesvos island, NE Aegean Sea, Greece), Journal of Natural History, 42(5-8), 597-618.

Evagelopoulos A., Koutsoubas D., Basset A., Pinna M., Dimitriadis C., Sangiorgio F., Barbone E., Maidanou M., Koulouri P. and Dounas C., (2008), Spatial and seasonal variability of the macrobenthic fauna in Mediterranean solar saltworks ecosystems. Aquatic Conservation: Marine \& Freshwater Ecosystems, 18, S118-S134.

Jumars P.A. and Nowell A.R.M., (1984), Effects of benthos on sediment transport: difficulties with functional grouping, Continental Shelf Research, 3 (2), 115-130.

Korovessis N.A. and Lekkas T.D., (2000), Solar saltworks production process evolution - wetland function. In: Saltworks: Preserving saline coastal ecosystems, Korovessis, N.A. and Lekkas, T.D. (eds.), 6th Conference on Environmental Science and Technology, Pythagorion, Samos, 1 September 1999, GlobalNEST, Athens.

Little C., (2000), The biology of shoft shores and estuaries, Biology of Habitats, Oxford University Press, Oxford.

McLusky D.S. and Elliott M., (2004), The estuarine ecosystem, Ecology, threats and management, 3rd edition, Oxford University Press, Oxford.

Oren A. (ed.) (2002), Halophilic microorganisms and their environments, Kluwer Academic Publishers, Dordrecht.

Panayotidis P. and Klaudatos S., (1997), Study of the structure and function of the marine and coastal ecosystem of Kalloni Bay, Lesvos Island, Report, National Centre of Marine Research (NCMR), Athens.

Pavlova P., Markova K., Tanev S. and Davis J., (1998), Observations on a solar saltworks near Burgas, Bulgaria, International Journal of Salt Lake Research, 7, 357-368.

Pedrós-Alió C., Calderón-Paz J., MacLean M., Medina G., Marrasé C. Gasol J. and GuixaBoixereu N., (2000), The microbial food web along salinity gradients, FEMS Microbiology Ecology, 32, 143-155.

Pennings S.C. and Bertness M.D., (2001), Salt marsh communities, In: Marine Community Ecology, Bertness, M.D. Gaines, S.D. and Hay, M.E. (eds.), Sinauer Associates, Sunderland.

Persoone G., Sorgeloos P., Roels O.A. and Jaspers E. (eds.) (1980), The brine shrimp Artemia: Proceedings of the International Symposium on the brine shrimp Artemia salina, Corpus Christi, Texas, USA, August 20-23, 1979, Volumes 1-3, Universa Press, Wetteren.

Reynolds, C., (2006), Ecology of phytoplankton, Cambridge University Press, Cambridge.

Sadoul N., Walmsley J.G. and Charpentier B., (1998), Salinas and nature conservation, Conservation of Mediterranean wetlands 9, Tour du Valat, Arles.

Rodriguez-Valera F., (1988), Characteristics and microbial ecology of hypersaline environments, In: Halophilic bacteria, Volume 1, Rodriguez-Valera, F. (ed.), CRC Press, Boca Raton.

Segal R., Maite A. and Hamilton D., (2006), Transition from planktonic to benthic algal dominance along a salinity gradient, Hydrobiologia, 556, 119-135.

Utermöhl H., (1958), Zur vervollkommnung der quantitativen phytoplankton-methodik, Mitteilung Internationale Vereinigung Theoretische unde Amgewandte Limnologie, 9, 1-38.

Vieira M.N. and Galhano M.H., (1985), First data about the ecology of the Aveiro saltponds (Portugal), Publicações do Instituto de Zoologia "Dr. Augusto Nobre" 109, Faculdade de Ciências do Porto, Porto.

Vieira N. and Amat F., (1997), The invertebrate benthic community of two solar salt ponds in Aveiro, Portugal, International Journal of Salt Lake Research, 5, 281-286.

Walmsley J.G., (2000), The ecological importance of Mediterranean salinas. In: Saltworks: Preserving saline coastal ecosystems, Korovessis, N.A. and Lekkas, T.D. (eds.), 6th Conference on Environmental Science and Technology, Pythagorion, Samos, 1 September 1999, GlobalNEST, Athens.

Williams J.A., (1996), Blooms of Mesodinium rubrum in Southampton Water - do they shape mesozooplankton distribution? Journal of Plankton Research, 18(9), 1685-1697. 